\title{
Comportamiento de morteros de cementos alcalinos reforzados con fibras acrílicas y de polipropileno
}

\author{
Behaviour of alkaline cement mortars reinforced with acrylic \\ and polypropylene fibres
}

Fecha de recepción: 19-01-00

Fecha de aceptación: 5-05-00
F.PLERTAS, T.AMAT, T.VÁZQI EZ Instituto de Ciencias de la Construcción Eduardo Torroja (CSIC)

ESPAÑA

\section{RESUMEN}

En el presente trabajo se estudia el comportamiento de morteros de cementos alcalinos reforzados con fibras de distinta naturaleza (acrilica y de polipropileno). Se ha evaluado también la estabilidad química de dichas fibras en medios fuertemente alcalinos. Se han utilizado tres matrices diferentes: escoria vitrea de horno alto activada con $\mathrm{NaOH}$ $2 M$, temperatura ambiente $\left(22^{\circ} \mathrm{C}\right)$; ceniza volante activada con $\mathrm{NaOH} 8 \mathrm{M}$, curada a $85^{\circ} \mathrm{C}$ durante 24 horas $y$ $50 \%$ ceniza/50\%escoria activada con $\mathrm{NaOH} 8 \mathrm{M}$, temperatura ambiente. El contenido de fibra fue del 0,2 y $1 \%$ en volumen de mortero. Los ensayos realizados fueron: tenacidad $e$ indice de tenacidad, resistencia al impacto y retracción al secado. Sobre las probetas ensayadas a impacto se realizó un estudio microestructural por SEM/EDX.

Los resultados obtenidos han demostrado que: a) Las fibras acrilicas y de polipropileno son estables en medios fuertemente básicos, aunque las primeras experimentan procesos de hidrólisis/hidratación que se manifiesta con alteración de su textura superficial. b) Con bajos contenidos en fibra $(0,2 \%$ en volumen), la tenacidad y el indice de tenacidad de estos morteros no se ve afectado. Con contenidos superiores (1\%) se produce un incremento en los correspondientes valores. Este incremento es mayor en los morteros de escoria activada alcalinamente. c) Para las tres matrices estudiadas, las fibras de polipropileno incrementan la resistencia al impacto en mayor medida que las fibras acrilicas. El efecto de refuerzo es más significativo en la matriz que contiene escorias y cuando el contenido de fibra es del $1 \%$ en volumen. d) La retracción al secado de estos morteros se modifica dependiendo del tipo de matriz y fibra. En los morteros de escoria activada, las fibras no reducen la retracción. En los morteros de ceniza activada reforzados con las fibras acrilicas, la retracción es menor que cuando contienen fibras de polipropileno o carecen de ellas. Finalmente, en los morteros de cenizalescoria activada, las dos fibras reducen la retracción al secado.

\section{SUMMARY}

In the present work, the behaviour of alkaline cement mortars reinforced with fibres of different nature (acrylic and polypropylene fibres) is studied. Also the chemical stability of those fibres in strong alkaline medium has been' investigated. Three different matrixes have been used: glass blast furnace slag activated with $\mathrm{NaOH} 2 \mathrm{M}$ (room temperature, $22{ }^{\circ} \mathrm{C}$ ); fly ash activated with $\mathrm{NaOH} 8 \mathrm{M}$, cured at $85{ }^{\circ} \mathrm{C}$ during 24 hours and 50\% fly ash $150 \%$ slag activated with $\mathrm{NaOH} 8 \mathrm{M}$, room temperature. The fibre content was 0,2 and $1 \%$ in mortar volume. The tests carried out were: tenacity and tenacity index, impact resistance and drying shrinkage. On the specimens tested, a microstructural study by SEM/EDX was carried out.

The results obtained have demonstrated the following: a) The acrylic and polypropylene fibres are stable in strong basic media, although the first undergo hydrolysis/ hydration processes showed by the alteration of the surface texture. b) with low fibre contents $(0,2 \%$ in volume), tenacity and tenacity index of these mortars remain unaffected. With higher contents (1\%), an increase of the corresponding values is produced. This increment is higher in mortars with alkaline activated slag. c) For the three matrixes studied, the polypropylene fibres increase the impact strength in higher degree than the acrylic ones. The reinforcement effect is more significative in matrix $A$ and when the fibre content is $1 \%$ in volume. d) the shrinkage of these mortars is modified depending on the matrix and fibre type. In mortars of activated slag, fibres do not reduce the shrinkage. In mortars of activated fly ash reinforced with acrylic fibres, shrinkage is lower than those containing polypropylene fibres are. Finally, in mortars of fly ash/ activated slag, the two fibres decrease the drying shrinkage. 


\section{INTRODUCCIÓN}

El desarrollo de nuevos conglomerantes, alternativos a los cementos y hormigones tradicionales, por la activación alcalina de distintos subproductos industriales (escorias de horno alto y cenizas volantes) es tema de estudio e investigación en la actualidad, por parte de la comunidad científica. Estos nuevos cementos se caracterizan por presentar elevadas prestaciones mecánicas y no requerir en su elaboración ni los elevados consumos energéticos ni las elevadas emisiones de gases contaminantes $\left(\mathrm{CO}_{2}, \mathrm{SO}_{2}, \mathrm{NO}_{x}\right.$, etc.) que son inherentes al proceso de fabricación de los cementos portland. Dependiendo de los materiales de partida, ya sean estos escorias de horno alto $y / 0$ cenizas volantes se desarrollan diferentes productos de reacción y microestructuras, lo cual va a conferir al cemento final diferencias en comportamiento $y$ propiedades.

Los cementos y hormigones resultantes de la activación alcalina de escorias vítreas de horno alto se caracterizan por presentar algunas ventajas evidentes respecto a los cementos y hormigones tradicionales, como más rápidas y mayores resistencias mecánicas (pueden superar los $100 \mathrm{Mpa}$ a los 28 días), menor calor de hidratación y mayor resistencia al ataque químico. También presentan algunas desventajas como fraguados muy rápidos y elevadas retracciones y formación de microfisuras (1). La activación alcalina de escorias de horno alto ha sido muy estudiada (2-6), su principal producto de reacción es un silicato cálcico hidratado tipo gel CSH. Esta fase gel se diferencia de la de una pasta de cemento portland por una menor relación $\mathrm{CaO} / \mathrm{SiO}_{2}$ y por otras diferencias estructurales (mayor incorporación de Al en su estructura) (7). La formación de otras fases o compuestos hidratados va a depender del tipo y cantidad del activador utilizado, de la estructura y composición de la escoria y las condiciones de curado bajo las cuales se va a producir el endurecimiento.

La activación alcalina de cenizas volantes silicoaluminosas da lugar, también, a productos de reacción cementantes. En este proceso de activación la temperatura de reacción juega un papel decisivo. A temperatura ambiente la velocidad de las reacciones es muy baja, sin embargo si el proceso ocurre a temperaturas entre $40-85^{\circ} \mathrm{C}$, la velocidad de las reacciones se incrementa notablemente, pudiéndose obtener morteros que desarrollan, a las 2 horas de curado, resistencias a flexotracción superiores a los 20 Mpa. Esta activación ha sido mucho menos estudiada. El producto de reacción generado en este tipo de activación es un polímero inorgánico de naturaleza amorfa y estructura tridimensional formado por cadenas de silicoaluminatos hidratados, donde las

\section{INTRODUCTION}

The development of new binders, alternative to traditional cement and concretes, obtained by the alkaline activation of different industrial byproducts (blast furnace slags and fly ashes) is an ongoing study and research topic of the scientifical community. These new cements are characterised by high mechanical performance and low energy cost and low pollutant gases emission $\left(\mathrm{CO}_{2}, \mathrm{SO}_{2}, \mathrm{NO}_{x^{\prime}}\right.$ etc.) which are generated in the manufacturing process of portland cement. Depending on the raw materials, blast furnace slags or fly ashes, different reaction products and microstructures are developed giving the final cement differences in its behaviour and properties.

Cements and concretes resultant from the alkaline activation of blast furnace slag are characterised by their advantages upon traditional cements and concretes as earlier and higher mechanical strengths (they can reach $100 \mathrm{Mpa}$ at 28 days), lower heat of hydration and higher resistance to chemical attack. They also present some disadvantages as rapid setting and high shrinkage with formation of crackings (1). The alkaline activation of blast furnace slags has been extensively studied (2-6), its main reaction product is a hydrated calcium silicate like a CSH gel type. This gel phase is differentiated from that of the portland cement one by a lower $\mathrm{CaO} / \mathrm{SiO}_{2}$ ratio and other structural differences (higher Al content in its structure) (7). The formation of other phases or hydrated compounds will depend on the activator type and quantity, the slag structure and composition and curing conditions.

The alkaline activation of aluminosilicate fly ashes also gives place to cementitious reaction products. In this activation process the reaction temperature plays an important role. At room temperature, reactions rate is very low, however, if the process occurs at temperatures between $40-85^{\circ} \mathrm{C}$, the reactions rate is notably increased, obtaining mortars developing flexural strengths higher than 20 Mpa at two hours of curing. This activation has been less studied. The reaction product obtained in this type of activation is an inorganic polymer of amorphous nature and tridimensional structure 
cargas negativas quedan neutralizadas por los iones alcalinos (8-10).

También se pueden obtener cementos alternativos cuando el material de partida es una mezcla de escorias vítreas de horno alto y cenizas volantes silicoaluminosas. Estos cementos alcalinos son menos conocidos, aunque estudios recientes (11) han demostrado que en mezclas del $50 \%$ ceniza $/ 50 \%$ escoria activadas a temperatura ambiente desarrollan resistencias mecánicas a compresión superiores a los $50 \mathrm{Mpa}$ a los 28 días de curado. El principal producto de hidratación en estas mezclas es un silicato cálcico hidratado, tipo gel CSH con $\mathrm{Al}$ y $\mathrm{Na}$ incorporado en su estructura.

Una posible solución tecnológica, a los problemas de retracción al secado y formación de fisuras que experimentan los morteros y hormigones de cementos de escorias activadas, así como a la aparente fragilidad en los morteros de cenizas activadas alcalinamente, es la incorporación a las mezclas de determinados tipos de fibras a modo de refuerzo.

La fibra, dependiendo de su naturaleza y tipo, puede mejorar ciertas características y propiedades de los morteros y hormigones, tales como: resistencia a la tracción, flexión, torsión, cortante, fatiga, impacto, tenacidad, retracción al secado, etc.

En el presente trabajo se estudia el comportamiento de morteros de cementos alcalinos reforzados con fibras de distinta naturaleza (acrílica y de polipropileno). Se evalúa también la estabilidad química de dichas fibras en medios fuertemente alcalinos.

\section{EXPERIMENTAL}

\subsection{Materiales}

\subsubsection{Matrices}

Se utilizaron tres matrices diferentes de cementos alcalinos que se obtuvieron por la activación alcalina de los siguientes materiales:

-Escoria granulada de horno alto (procedente de Ensidesa, Avilés)

-Ceniza volante (procedente de la Central Térmica de Aboño)

-Mezcla de un 50\% ceniza volante de Aboño y 50\% de escoria granulada de Ensidesa

En la Tabla 1 se presentan los análisis químicos de la ceniza volante y la escoria de horno alto utilizadas. formed by hydrated aluminosilicates, where negative charges are balanced by alkaline ions (8-10).

Alternative cements can also be obtained when the raw material is a mix of granulated blast furnace slags and aluminosilicate fly ashes. These alkaline cements are less known, although recent studies (11) have demonstrated that in mixes of 50\% fly/ash 50\% slag activated at room temperature, compressive strengths higher than $50 \mathrm{Mpa}$ are developed at 28 days of curing. The main hydration product in these mixes is a hydrated calcium silicate of the CSH gel type with $\mathrm{Al}$ and $\mathrm{Na}$ in its structure.

A possible technological solution to the drying shrinkage and the formation of crackings of mortars and concretes of activated blast furnace slags, likewise the apparent brittleness of the alkaline activated fly ashes is the incorporation to the mixes of reinforcement fibres.

Depending on the nature and type of the fibre, determined characteristics and properties of mortars and concretes can be improved as: traction strength, flexural strength, torsion, cut, fatigue, impact, tenacity, drying shrinkage, etc.

In the present work, the behaviour of alkaline cements reinforced with fibres of different nature (acrylic and polypropylene ones) is studied. Also the chemical stability of those fibres in strong alkaline media is evaluated.

\section{EXPERIMENTAL}

\subsection{Materials}

\subsubsection{Matrixes}

Three different matrixes of alkaline cements were used :

-Granulated blast furnace slag (from Ensidesa, Avilés)

-Fly ash (from Aboño

Thermal Central)

-Mix of 50\% Aboño fly ash and 50\% granulated slag from Ensidesa

The chemical analysis of fly ash and blast furnace slag is shown in Table 1. 
TABLA 1 (TABLE 1)

Composición química (\% en masa) (Chemical composition (\% mass)

\begin{tabular}{||c|c|c||}
\hline & Ceniza volante (Fly ash) & Escoria (Slag) \\
\hline $\mathrm{CaO}$ & 5,51 & 41,45 \\
$\mathrm{SiO}_{2}$ & 51.49 & 35,50 \\
$\mathrm{Al}_{2} \mathrm{O}_{3}$ & 29,03 & 12,15 \\
$\mathrm{Fe}_{2} \mathrm{O}_{3}$ & 7,76 & 1,01 \\
$\mathrm{MgO}$ & 2,35 & 8,34 \\
$\mathrm{SO}_{3}$ & ---18 \\
$\mathrm{~S}^{-2}$ & -- & 0,18 \\
$\mathrm{Na}_{2} \mathrm{O}$ & 0,66 & 0,92 \\
$\mathrm{~K}_{2} \mathrm{O}$ & 2,83 & 0,58 \\
Blaine $\left(\mathrm{m}^{2} / \mathrm{kg}\right)$ & 398 & 0,64 \\
\hline
\end{tabular}

TABLA 2 (TABLE 2)

Características de las fibras (Fibres characteristics)

\begin{tabular}{||c|c|c||}
\hline & Acrílica (Acrylic) & Polipropileno (Polypropylene) \\
\hline Densidad $(\mathrm{g} / \mathrm{cc})($ Density $(\mathrm{g} / \mathrm{cc}))$ & 1,18 & 0,9 \\
\hline Diámetro $(\mu \mathrm{m})($ Diameter $(\mu \mathrm{m}))$ & 80 & 18 \\
\hline Longitud $(\mathrm{mm})($ Length $(\mathrm{mm}))$ & 15 & 12 \\
\hline
\end{tabular}

Las sustancias activadoras fueron disoluciones de diferentes concentraciones de $\mathrm{NaOH}$. $\mathrm{El} \mathrm{NaOH}$ utilizado fue reactivo químico marca Panreac.

\subsubsection{Fibras}

Se emplearon dos fibras distintas:

-Acrílica SEKRIL (S-940)

-Polipropileno CRACKSTOP

En la Tabla 2 se dan algunas características de las fibras utilizadas.

Previo a la introducción de las fibras en los morteros, se estudió la estabilidad química de las mismas en medios fuertemente alcalinos. Estos medios eran similares a los que existentes en los morteros finales. Para ello se sumergieron las fibras en disoluciones de $\mathrm{NaOH}$, con una concentraciones de $2 \mathrm{M}$ y $10 \mathrm{M}$. La temperatura fue otra variable del proceso, de manera que para cada concentración, se mantuvo las mezclas disolución $\mathrm{NaOH} /$ fibra a temperatura ambiente y otra porción se mantuvo durante 5 horas a $65^{\circ} \mathrm{C}$. A edades prefijadas, 8 semanas y 6 meses, las fibras fueron extraídas de las disoluciones y examinadas por FTIR y SEM/EDX. Para la obtención de los espectros de FTIR se utilizó el método del "comprimido de $\mathrm{KBr}$ ".
The activators were $\mathrm{NaOH}$ solutions of different concentrations. $\mathrm{NaOH}$ was chemical degree reactant Panreac.

\subsubsection{Fibres}

Two different fibres were used:

-Acrylic SEKRIL (S-940)

-Polypropylene CRACKSTOP

Some characteristics of the fibres are shown in Table 2:

Before the introduction of the fibres in mortars, the chemical stability of them in strong alkaline media was studied. These media were similar to those existing in the final mortars. For this purpose, fibres were immersed in $\mathrm{NaOH}$ solutions with $2 \mathrm{M}$ and $10 \mathrm{M}$ concentration. Temperature was other parameter of the process and, for each concentration the mixes $\mathrm{NaOH} / f i b r e$ were maintained at room temperature and other portion was maintained at $65{ }^{\circ} \mathrm{C}$ during 5 hours. At determined ages, 8 weeks and 6 months, fibres were removed from solutions and examined by FTIR and SEM/EDX. For the obtention of FTIR spectra, $\mathrm{KBr}$ pellets method was used. 


\subsection{Variables del proceso. Ensayos realizados}

Las variables que se contemplaron en el presente trabajo fueron:

-Tipo de matriz y temperatura de curado:

-Escoria vítrea de horno alto activada con $\mathrm{NaOH} 2 \mathrm{M}$, temperatura ambiente $\left(22^{\circ} \mathrm{C}\right.$ ) (MATRIZ A)

-Ceniza volante activada con $\mathrm{NaOH} 8 \mathrm{M}$, curada a $85^{\circ} \mathrm{C}$ durante 24 horas (MATRIZ B)

$-50 \%$ ceniza $/ 50 \%$ escoria activada con $\mathrm{NaOH} 8 \mathrm{M}$, temperatura ambiente (MATRIZ C)

La selección de estas matrices se hizo atendiendo a investigaciones anteriores.

-Tipos de fibra: acrílica y de polipropileno

-Porcentaje de fibra: 0,2 y $1 \%$ en volumen de mortero

Teniendo en cuenta estas variables se prepararon morteros de distinto tamaño dependiendo del ensayo a realizar. La preparación de los morteros se hizo siempre de acuerdo a la norma UNE 83-821-92. En la elaboración de los morteros se utilizó, arena silícea normalizada, con una riqueza en cuarzo del $99,9 \%$ en masa. La relación líquido de amasado/material cementante se mantuvo constante en 0,5. En todos los ensayos se prepararon probetas exentas de fibras que fueron consideradas como muestras de referencia.

\subsubsection{Ensayo de Tenacidad e Indice de Tenacidad a flexotracción}

Se prepararon en el laboratorio series de tres probetas prismáticas de cada mortero de $4 \times 4 \times 16 \mathrm{~cm}$. La determinación de la tenacidad se realizó sobre las probetas preparadas a los 28 días de reacción.

La máquina de ensayo fue un dinamómetro Instron 1114. El ensayo se realizó siguiendo la norma UNE 83-510, registrándose el diagrama carga-flecha con el fin de determinar la Tenacidad y el Indice de Tenacidad. La velocidad de deformación fue constante en $0,2 \mathrm{~mm} / \mathrm{min}$. La metodología utilizada ya fue descrita en trabajos anteriores (12).

\subsubsection{Resistencia al Impacto}

Se prepararon probetas de mortero de $16 \times 14 \times 2,5 \mathrm{~cm}$. El impacto se realizó mediante una esfera de $540 \mathrm{~g}$, mantenida por un electroimán a una altura de $100 \mathrm{~cm}$ de la cara superior de la probeta. Con este sistema se determina la cantidad de energía de impactos precisa para producir la primera fisura y rotura total de las piezas. Los ensayos se realizaron a los 28 días de reacción.

\subsection{Process variables. Tests carried out}

The variables tested in this work were:

-Type of matrix and curing temperature:

-Granulated blast furnace slag activated with $2 \mathrm{M} \mathrm{NaOH}$ solution, cured at room temperature $\left(22^{\circ} \mathrm{C}\right)$ (MATRIX A) -Fly ash activated with $8 \mathrm{MNOOH}$ solutions cured at $85^{\circ} \mathrm{C}$ during 24 hours (MATRIX B)

$-50 \%$ fly ash $/ 50 \%$ slag activated with $8 \mathrm{M} \mathrm{NaOH}$ solution, room temperature (MATRIX C)

The selection of these matrixes was chosen according to previous investigations.

-Types of fibres: acrylic and polypropylene type -Fibre percentage: 0,2 and 1\% of mortar volume

Considering these variables, mortars of different sizes were elaborated depending on the test carried out. The mortars elaboration was always done according to the Spanish Standard UNE 83-821-92. In mortars elaboration, siliceous standardised sand with a 99,9\%, quartz content was used. The mixing liquid/cementitious material ratio was kept constant at 0.5. In all the tests, specimens without fibres considered as reference were prepared

\subsubsection{Tenacity test and flexural tenacity index}

Series of three prismatic specimens of $4 \times 4 \times 16 \mathrm{~cm}$ of each mortar were prepared. The tenacity determination was carried out on specimens at 28 days of reaction.

The test machine was an Instron 1114 dynamometer. The test was carried out according to the Spanish standard UNE 83-510, recording the diagram load-pointer in order to determine the tenacity and tenacity index. The deformation rate was constant and equal to $0,2 \mathrm{~mm} / \mathrm{min}$. The methodology used was described in previous works (12).

\subsubsection{Impact Strength}

Mortars specimens of $16 \times 14 \times 2,5 \mathrm{~cm}$ were prepared. The impact was carried out by means of a sphere of $540 \mathrm{~g}$, maintained by an electromagnet at $100 \mathrm{~cm}$ from the upper surface of the specimen. With this system, the amount of impact energy enough to produce the first crack and total breakness of the specimens is measured. The tests were carried out at 28 days of reaction. 


\subsubsection{Estudio microestructural}

Sobre las probetas ensayadas a impacto se realizó un examen por microscopía electrónica de barrido y sistema microanalítico (SEM/EDX), con el fin de caracterizar microestructuralmente los morteros reforzados.

\subsubsection{Retracción al secado}

Los ensayos de retracción al secado se han realizado de acuerdo a la norma ASTM C 806-87. La primera determinación se realizó a las $6 \mathrm{~h}$ del amasado, las restantes mediciones se realizaron a las $24 \mathrm{~h}, 48 \mathrm{~h}$, hasta un tiempo máximo de 21 días. En estos ensayos el contenido de fibras fue del $0,2 \%$.

\section{RESULTADOS Y DISCUSIÓN}

\subsection{Estabilidad de las fibras en medios fuertemente alcalinos}

En las Figuras 1 y 2 se presentan los espectros de FTIR obtenidos de las fibras, acrílicas y de polipropileno, respectivamente, tras mantenerlas en las disoluciones alcalinas. De estas figuras se deduce que todos los espectros de la fibra acrílica (antes y después del tratamiento) son muy similares, salvo en la zona correspondiente a vibraciones $v(\mathrm{OH})$. En el espectro de la fibra acrílica no tratada se observa una banda ancha en $3.450 \mathrm{~cm}^{-1}$. En los del resto de las muestras destacan en la misma zona la presencia de dos bandas también anchas hacia 3.636 y $3.543 \mathrm{~cm}^{-1}$. De acuerdo con F. Acción et al. (13), el agua presente en la estructura de la fibra se incorpora a través de diferentes formas: en un primer paso lo hace a través de los grupos nitrilo; posteriormente puede suceder un proceso de hidratación más amplio por el cual las moléculas de agua forman puentes de hidrógeno entre grupos ester, que se hidrolizan parcialmente si las fibras están introducidas en medio básico generando el correspondiente carboxilato.

Los espectros IR de la fibra de polipropileno, tanto el correspondiente a la muestra no tratada, como de las muestras posteriores al tratamiento, son idénticos, lo que se interpreta como que las distintas disoluciones de $\mathrm{NaOH}$ no alteran la composición de la fibra.

El estudio microestructural realizado por SEM/EDX sobre las fibras tras su conservación en las disoluciones alcalinas durante 6 meses, ha mostrado que las fibras acrílicas experimentan procesos de alteración superficial, con signos de disolución (ver Figura 3). Este efecto es observado en las fibras

\subsubsection{Microstructural study}

On the specimens tested in the impact test, an exam was done by scanning electron microscopy and microanalytical system (SEM/EDX) in order to characterise the microstructure of the reinforced mortars.

\subsubsection{Drying shrinkage}

The tests for drying shrinkage were carried out according to the ASTM C 806-87 standard. The first determination was carried out at 6 hours of mixing, the rest of measurements was done at 24, 48 hours up to a maximum time of 21 days. The fibres content in these tests was $0,2 \%$.

\section{RESULTS AND DISCUSSION}

\subsection{Stability of the fibres in strong alkaline media}

In Figures 1 and 2, FTIR spectra of the acrylic and polypropylene fibres after they are immersed in alkaline media are shown. From these figures it is deduced that all the spectra of the acrylic fibres (before and after the treatment) are very similar, except for the region corresponding to $(\mathrm{OH})$ vibrations. In the spectrum of the untreated acrylic fibre a broad band at $3.450 \mathrm{~cm}^{-1}$ is observed. The rest of the spectra are two broad bands at 3.636 and $3.543 \mathrm{~cm}^{-1}$.are observed. According to F. Acción et al. (13), the water present in the fibre structure is incorporated through different forms: in a first stage through nitrile groups; later, a hydration process in higher degree may occur in which water molecules form hydrogen bridges among ester groups that partially hydrolize if fibres are incorporated in basic media generating the corresponding carboxilate group.

IR spectra of polypropylene fibres, those of the treated and untreated samples are identical which is interpretated considering that $\mathrm{NaOH}$ solutions do not altere the composition of the fibre.

The microstructural study carried out by SEM/EDX on fibres after their treatment in alkaline solutions during 6 months, shows that acrylic fibres undergo processes of surface alteration, with signs of dissolution (see Figure 3). This effect is observed in fibres maintained in $10 \mathrm{M} \mathrm{NaOH}$ solution, at room 


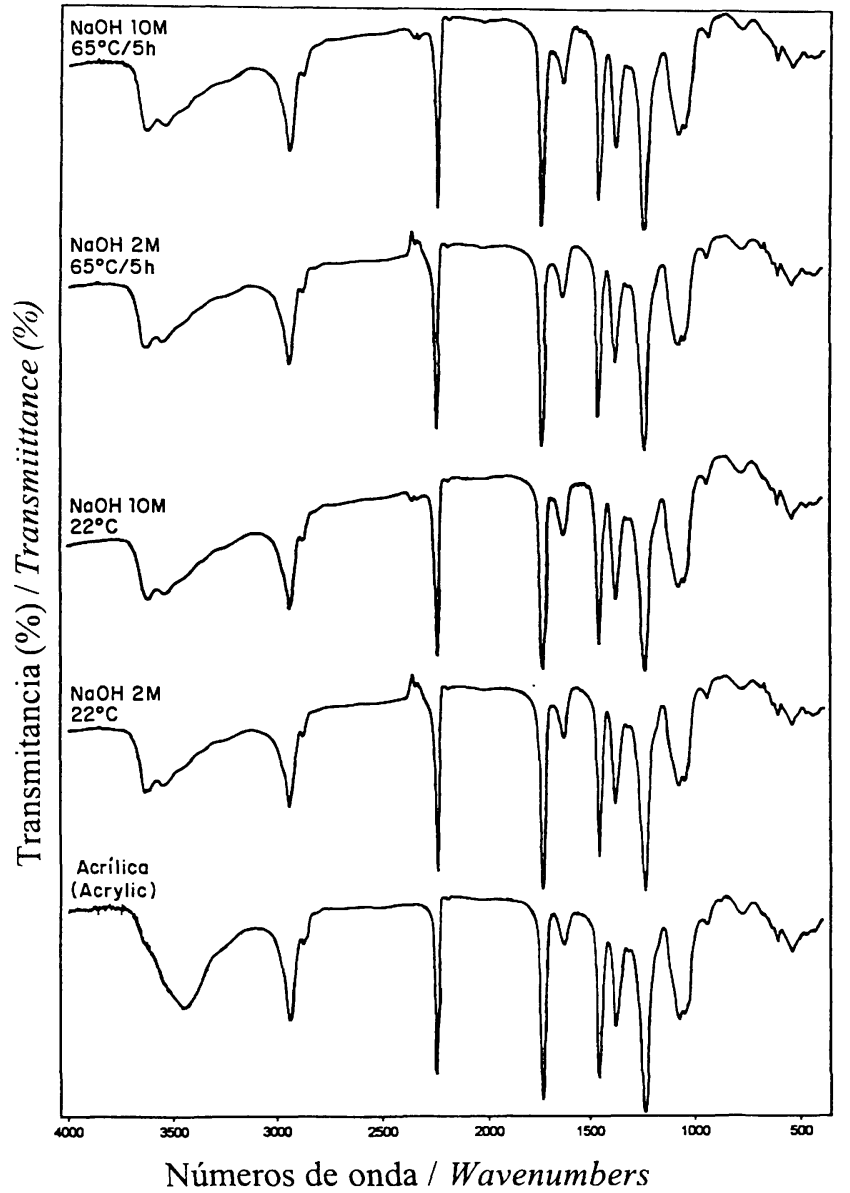

Figura 1.- Espectros de FTIR de las fibras acrílicas tras 6 meses de permanecer en las disoluciones alcalinas.

Figure 1.- FTIR spectra of acrylic fibres inmersed in alkaline solutions during 6 months.

mantenidas en la disolución de $\mathrm{NaOH} 10 \mathrm{M}$, tanto a las tratadas a temperatura ambiente como las calentadas a $65^{\circ} \mathrm{C}$ durante las 5 primeras horas. La existencia de los procesos de hidrólisis o de hidratación descritos por FTIR justifican los cambios texturales observados.

Las fibras de polipropileno mantenidas en las mismas disoluciones muestran menos signos de alteración superficial que las acrílicas. El efecto de la temperatura es algo más marcado ya que la fibra tratada a $65^{\circ} \mathrm{C}$ presenta en algunas zonas de su superficie señales de alteración como puede observarse en la Figura 4.

\subsection{Tenacidad e Indice de Tenacidad a flexotracción}

Los resultados obtenidos se presentan en la Tablas 3, 4 y 5. El análisis de estos resultados muestra que cuando las fibras (tanto las acrílicas como las de

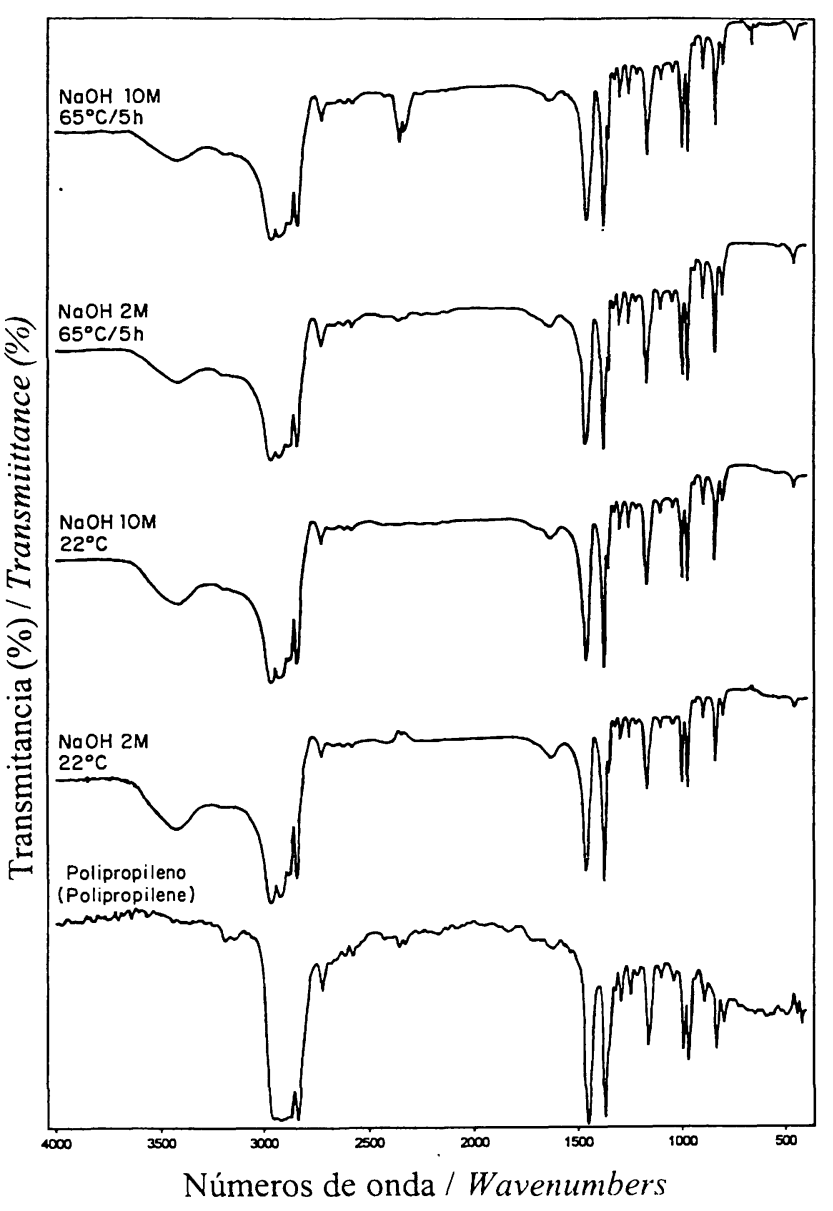

Figura 2.- Espectros de FTIR de las fibras de polipropileno tras 6 meses de permanecer en las disoluciones alcalinas.

Figure 2.- FTIR spectra of polypropylene fibres inmersed in alkaline solutions during 6 months.

temperature and in those maintained at 65 "C during the first 5 hours. The existence of hydrolysis or hydration processes described by FTIR explain the textural changes observed.

The polypropylene fibres maintained in the same solutions show less alteration signs. The effect of temperature is some more marked because the fibre treated at $65^{\circ} \mathrm{C}$ present some alterations of the surface as it is observed in Figure 4.

\subsection{Tenacity and flexural Tenacity Index}

The results obtained are presented in Tables 3, 4, and 5. The analysis of these results show that fibres (acrylic and polypropylene ones) are added to 


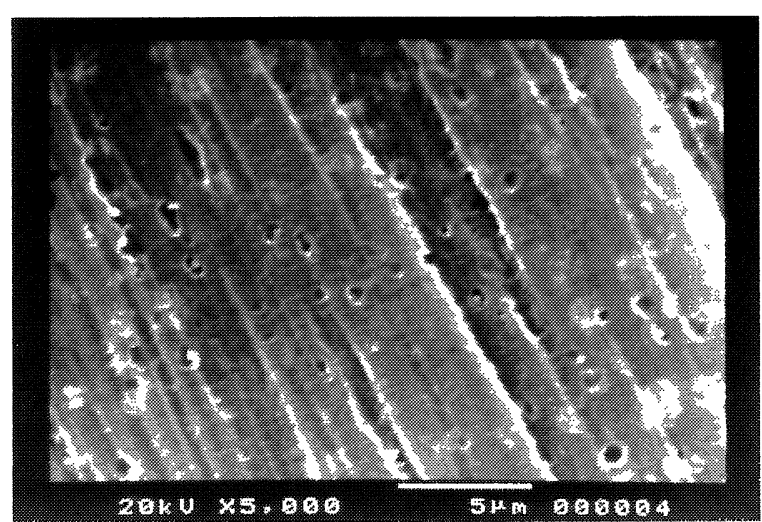

Figura 3.- Fibra acrílica mantenida en $\mathrm{NaOH} 10 \mathrm{M}$ durante 6 meses y a temperatura ambiente.

Figure 3.- Acrylic fibre inmersed in $10 \mathrm{M} \mathrm{NaOH}$ solution at room temperature during 6 months.

polipropileno) se adicionan a los morteros en un contenido del $0,2 \%$ en volumen, no se modifica ni la carga de rotura ni la flecha para la formación de la primera fisura. Este efecto se observa también cuando el contenido de la fibra es del $1 \%$ en volumen. El comportamiento sobre la tenacidad y el índice de tenacidad es diverso con contenidos del $1 \%$ en volumen, el efecto depende del tipo de fibra y de la naturaleza de la matriz. Con la matriz A (escoria activada) se produce un incremento de la tenacidad y del índice de tenacidad, alcanzado valores superiores a 8. Esto se produce tanto con las fibras acrílicas como las de polipropileno. En la matriz C (ceniza/escoria activada) el incremento de la tenacidad es menor, tomando valores de índice de tenacidad del orden de 45 con la fibra acrílica y del orden de 6 con la de polipropileno. Finalmente, con la matric B (ceniza activada), las fibras acrílicas no incrementan la resistencia de estos materiales y las de polipropileno lo hacen muy pobremente, el índice de tenacidad toma valores del orden de 4

La tenacidad mide la capacidad de absorción de energía del mortero u hormigón. Es una propiedad del material compuesto y su valor depende no sólo del volumen, longitud y tipo de fibra sino también de las características de la matriz. El índice de tenacidad depende del tipo, contenido y longitud de las fibras; las características de la matriz apenas si influyen en su valor (12). Los resultados obtenidos con estas matrices de materiales activados alcalinamente muestran que las fibras, en contenidos bajos $(0,2 \%)$ no refuerzan y que contenidos mayores ( $1 \%$ ) mejoran algo la tenacidad, de modo similar a como lo hacen estas mismas fibras en matrices de cemento (12). Esta pequeña variación en los valores de tenacidad, tanto con 0,2 como $1 \%$, es debido, por una parte, a que las matrices utilizadas

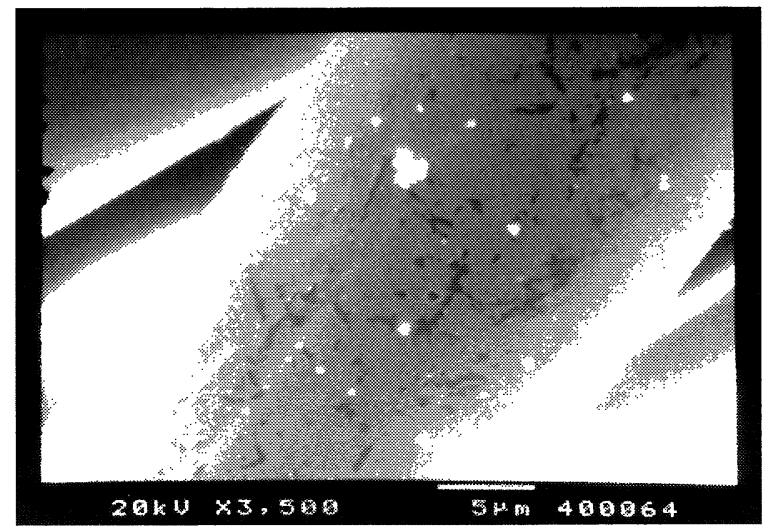

Figura 4.- Fibra de polipropileno mantenida en $\mathrm{NaOH} 10 \mathrm{M}$ y $65^{\circ} \mathrm{C}$, durante 6 meses.

Figure 4.- Polypropylene fibre inmersed in $10 \mathrm{M} \mathrm{NaOH}$ solution at $65^{\circ} \mathrm{C}$ during 6 months.

mortars in $0,2 \%$ content in volume, breakness load and deflection are not modified for the formation of the first crack. This effect is also observed when fibre content is $1 \%$ in volume. The behaviour upon tenacity and tenacity index is diverse with contents of $1 \%$ in volume. The effect depends on the fibre type and the nature of the matrix. With matrix $A$ (activated slag) an increase in tenacity and tenacity index is produced reaching values higher than 8. This is produced with acrylic fibres and polypropylene ones. In matrix $C$ (fly ash/activated slag) the tenacity increase is lower, with values of tenacity index of 4-5 with acrylic fibre and 6 with polypropylene one. Finally, with matrix $B$ (activated fly ash), acrylic fibres do not increase the materials strength and polypropylene fibres increase them in low degree, tenacity index is of about 4.

Tenacity measures the capacity of energy absorbance of the mortar or concrete. This is a property of the composite material and its value depends on volume, length and fibre type and also on the matrix characteristics. Tenacity index depends on the type, content and length of the fibres; matrix characteristics have little influence (12). The results obtained with these matrices of alkaline activated material show that fibres, in low contents $(0,2 \%)$ do not reinforce and higher contents (1\%) improve the tenacity the same as they do in cement matrices. This small variation in tenacity values is due, by one hand 
TABLA 3 (TABLE 3)

Resultados a tenacidad (Tenacity results)

\begin{tabular}{|c|c|c|c|c|c|}
\hline & \multicolumn{5}{|c|}{$\begin{array}{c}\text { MATRIZ A (MATRIX A) } \\
\text { (ESCORIA ACTIVADA) (ACTIVATED SLAG) }\end{array}$} \\
\hline & \multicolumn{2}{|c|}{$1^{10}$ Fisura $\left(I^{*}\right.$ Crack $)$} & \multirow{2}{*}{$\begin{array}{c}\text { TENACIDAD } \\
\text { I' FISURA } \\
\text { (TENACITY } \\
\left(I^{\prime \prime} \text { KRACK) }\right. \\
(\mathrm{J})\end{array}$} & \multirow{2}{*}{$\begin{array}{c}\text { TENACIDAD } \\
\text { TEENACITY } \\
(1 / 150) \\
(1)\end{array}$} & \multirow{2}{*}{$\begin{array}{c}\text { INDICE } \\
\text { TENACIDAD } \\
\text { TENACCTY } \\
\text { RATE) }\end{array}$} \\
\hline & $\begin{array}{c}\text { CARGA } \\
\text { ROAD) } \\
(\mathrm{KN})\end{array}$ & $\begin{array}{c}\text { FLECHA } \\
(D E R E C T I O N) \\
(\mathrm{mm}) \\
\end{array}$ & & & \\
\hline $\begin{array}{c}\text { REFERENCIA } \\
\text { (sTANDARD) } \\
\text { Sin fibra (Withoul fibre) }\end{array}$ & 1.564 & 0.110 & 0.086 & 0.152 & 2,82 \\
\hline $\begin{array}{c}0,22 \\
\text { ACRILICA (ACRILIC) } \\
\end{array}$ & 1,299 & 0.116 & 0,076 & 0,293 & 4,13 \\
\hline $\begin{array}{c}1 \% \\
\text { ACRILICA (ACRIIC) } \\
\end{array}$ & 1.468 & 0.126 & 0,092 & 0,575 & 8,22 \\
\hline $\begin{array}{c}0,2 \% \\
\text { POLIPROPILENO } \\
\text { (POLYPROPROPYLNE) }\end{array}$ & 1.180 & 0,110 & 0,065 & 0,287 & 4.95 \\
\hline $\begin{array}{c}1 \% \\
\text { POLPROPILENO } \\
\text { (POLYPROPMENE) } \\
\end{array}$ & 1.248 & 0.132 & 0,082 & 0.515 & 8.03 \\
\hline
\end{tabular}

TABLA 4 (TABLE 4)

Resultados a tenacidad (Tenacity results)

\begin{tabular}{|c|c|c|c|c|c|}
\hline & \multicolumn{5}{|c|}{$\begin{array}{l}\text { MATRIZ B (M.ATRXI B) } \\
\text { (CENIZA ACTIVADA) (ACTIVATED FLY ASH) }\end{array}$} \\
\hline & \multicolumn{2}{|c|}{$1^{\circ}$ Fisura ( $\left(1^{\prime \prime}\right.$ Crack) } & \multirow{2}{*}{$\begin{array}{c}\text { TENACIDAD } \\
\text { I }^{*} \text { FISURA } \\
\text { (TENACITn } \\
\left(l^{\prime \prime} \text { CRACK) }\right. \\
\text { (J) }\end{array}$} & \multirow{2}{*}{$\begin{array}{l}\text { TENACIDAD } \\
\text { (TENACITn } \\
\text { (1/1/50) } \\
\text { (J) }\end{array}$} & \multirow{2}{*}{$\begin{array}{c}\text { INDICE } \\
\text { TENACIDAD } \\
\text { (TENACTTY } \\
\text { RATE) }\end{array}$} \\
\hline & $\begin{array}{l}\text { CARGA } \\
\text { (LOAD) } \\
(\mathrm{KN})\end{array}$ & $\begin{array}{c}\text { FLECHA } \\
(D E F Z E C T I O N) \\
(\mathrm{mm})\end{array}$ & & & \\
\hline $\begin{array}{c}\text { REFERENCIA } \\
\text { (STANDARD) } \\
\text { Sin fibra (Wilhoul) } \\
\end{array}$ & 2.375 & 0.151 & 0,178 & 0.251 & 1,41 \\
\hline $\begin{array}{c}0,2 \% \\
\text { ACRILICA (ACRYIC) }\end{array}$ & 2,055 & 1,144 & 0.076 & 0.240 & 1,62 \\
\hline $\begin{array}{c}1 \% \\
\text { ACRILICA (ACRYLIC) }\end{array}$ & 2,421 & 0.153 & 0.148 & 0.314 & 1,70 \\
\hline $\begin{array}{c}0.2 \% \\
\text { POL.IPROPILENO } \\
\text { (POLYYROPYLENE) } \\
\end{array}$ & 2,418 & 0.137 & 0.185 & 0.287 & 1.74 \\
\hline $\begin{array}{c}1 \% \\
\text { POLIPROPILENO } \\
\text { (POLYPROPYLENE) }\end{array}$ & 1,850 & 0,119 & 0.109 & 0.439 & 4,03 \\
\hline
\end{tabular}

TABLA 5 (TABLE 5)

Resultados a tenacidad (Tenacity results)

\begin{tabular}{|c|c|c|c|c|c|}
\hline & \multicolumn{5}{|c|}{$\begin{array}{c}\text { MATRIZ C (MATRIX C) } \\
\text { (ESCORIA ACTIVADA) (ACTIVATED F.Y ASHISLAG) }\end{array}$} \\
\hline & \multicolumn{2}{|c|}{$1^{*}$ Fisura $\left(l^{\prime \prime}\right.$ crack) } & \multirow{2}{*}{$\begin{array}{c}\text { TENACIDAD } \\
\text { 1 } 1 \text { FISURA } \\
\text { TENACITY } \\
\text { (l" CRACK) } \\
\text { (J) }\end{array}$} & \multirow{2}{*}{$\begin{array}{l}\text { TENACIDAD } \\
\text { (TENACITY) } \\
\text { (1/150) } \\
\text { (J) }\end{array}$} & \multirow{2}{*}{$\begin{array}{c}\text { INDICE } \\
\text { TENACIDAD } \\
\text { TENACITY } \\
\text { RATE }\end{array}$} \\
\hline & $\begin{array}{l}\text { CARGA } \\
\text { ROAD) } \\
\text { (KN) } \\
\end{array}$ & $\begin{array}{c}\text { FLECHA } \\
\text { (DEFECTION) } \\
(\mathrm{mm}) \\
\end{array}$ & & & \\
\hline $\begin{array}{c}\text { REFERENCIA } \\
\text { (STANDARD) } \\
\text { Sin libra (Withoul fibre) } \\
\end{array}$ & 1.564 & 0.110 & 0,086 & 0.175 & 2,03 \\
\hline $\begin{array}{c}0.2 \% \\
\text { ACRRLILA (ACRYLIC) }\end{array}$ & 1,541 & 0,139 & 0.107 & 0.283 & 2.65 \\
\hline $\begin{array}{c}1 \% \\
\text { ACRILICA (ACRYLIC) }\end{array}$ & 1,571 & 0.116 & 0.099 & 0,421 & 4.75 \\
\hline $\begin{array}{c}0.2 \% \\
\text { POLIPROPILENO } \\
\text { (POLYPROPYLENE) }\end{array}$ & 1,508 & 0.105 & 0,079 & 0.254 & 3.23 \\
\hline $\begin{array}{c}1 \% \\
\text { POLIPROPILENO } \\
\text { (POLYPROPYLENE) }\end{array}$ & 1,430 & 0,137 & 0,097 & 0.463 & 6,01 \\
\hline
\end{tabular}


tienen, ya de por sí, una elevada resistencia y compacidad y, por otra, a los bajos valores de módulos de elasticidad que tienen las fibras acrílicas y de polipropileno.

El peor comportamiento de los morteros de la matriz $\mathrm{B}$ respecto a los de las matrices $\mathrm{A}$ y $\mathrm{C}$ se puede justificar porque en la activación alcalina de cenizas se precisa no sólo de altas concentraciones (disolución de $\mathrm{NaOH}$ $10 \mathrm{M})$ sino también de elevadas temperaturas de reacción ( $85^{\circ} \mathrm{C}$ durante las primeras 24 horas). Ambas acciones conjuntas afectan a la estabilidad de las fibras y su papel de refuerzo se ve sensiblemente mermado.

\subsection{Resistencia al impacto}

En la Tabla 6 se presentan los resultados obtenidos. De esta tabla se deduce que en los morteros con las matrices B (ceniza activada) y C (ceniza/escoria activada) y contenidos bajos de fibra $(0,2 \%)$ no se incrementan las resistencias al impacto. Con la matriz A (escoria activada) sí se produce un incremento en el número de impactos precisos para la rotura, del orden de 4 veces más, no así para la formación de la primera fisura. Sin embargo, cuando el contenido de la fibra es mayor $(1 \%)$ y, muy especialmente, cuando ésta es de polipropileno, aumenta muy notablemente el número de impactos precisos para la rotura de la probeta, 18 veces más. Este efecto, es de menor entidad con las matrices $\mathrm{B}$ y $\mathrm{C}$.

Para todas las matrices estudiadas, las fibras de polipropileno incrementan la resistencia al impacto en mayor medida que las fibras acrílicas.

\subsection{Análisis microestructural de las superficies de fractura}

Tras el ensayo a impacto a los 28 días de curado, las probetas de morteros reforzadas con fibras (con contenidos del $1 \%$ en volumen) fueron analizadas por SEM/EDX. Los resultados obtenidos se describen y discuten, en función de la distinta naturaleza de las matrices utilizadas.

\section{Matriz A (escoria activada)}

El comportamiento de la fibra es diferente dependiendo de su naturaleza. La fibra acrílica se encuentra en los morteros con signos de evidente ataque superficial, con depósitos (ricos en $\mathrm{Na}$ ) y escamación a lo largo de toda su superficie. En la Figura 5 se puede ver con detalle el aspecto alterado de estas fibras. Ya en el estudio de estabilidad de las fibras se comprobó que la acrílica experimentaba únicamente degradación superficial en los medios fuertemente to the high strength and compacity of the used matrices by themselves and on the other to the low elasticity modules of the fibres.

The worse behaviour of matrix $B$ with respect to $A$ and $C$ matrices is explained considering that the alkaline activation of fly ashes requires not only high concentrations (10M NaOH solution) but also high reaction temperatures $\left(85^{\circ} \mathrm{C}\right.$ during the first 24 hours). Both joint actions affect the fibres stability lowering their reinforcement effect.

\subsection{Impact strength}

In Table 6, the results obtained are shown. Form this table it is deduced that mortars with matrices $B$ (activated fly ash) and $C$ (fly ash/slag) and low fibres contents $(0,2 \%)$ impact strengths are not increased. With matrix $A$ (activated slag) an increase is produced in the number of impacts necessary for breakness of 4 times or more, but not for the formation of the first crack. However, when fibre content is higher (1\%) and very especially when the fibre is polypropylene one the number of impacts necessary for the specimen breakness increase notably and it is 18 times higher. This effect is smaller with $B$ and $C$ matrixes.

For all matrixes studied, polypropylene fibres increase impact strength in higher degree than acrylic fibres.

\subsection{Microstructural analysis of the fracture surfaces}

After the impact test at 28 days, the specimens of mortars reinforced with fibres (with contents of $1 \%$ in volume) were analysed by $S E M / E D X$. The results obtained are described and discussed as a function of the nature of the matrixes used.

\section{Matrix A (activated slag)}

The behaviour of the fibre is different depending on its nature. The acrylic fibre in mortars is found with clear signs of surface attack, with Na rich deposits and flakes along the surface. In Figure 5, the details aspect of the fibres is observed. In the stability study was already verified the surface degradation of the fibres in strong alkaline media. The analysis of the 
alcalinos. El análisis de la huella dejada por la fibra (Figura 6) muestra una morfología diferente al resto de la pasta y un análisis también distinto. La huella es muy rica en Ca mientras que la matriz tiene el análisis característico de un gel tipo $\mathrm{CSH}$ con mayor proporción de $\mathrm{Al}$, tal y como es característico de estos materiales (7).

Cuando la fibra de refuerzo es de polipropileno, la superficie de ésta no esta practicamente alterada. Esto coincide con los resultados obtenidos en los estudios previos de estabilización de las fibras, y en el mejor comportamiento al impacto de los morteros de esta matriz reforzados con estas fibras frente a aquéllos que contienen las fibras acrílicas. La resistencia al impacto print left by the fibre (Figure 6) shows a different morphology than the rest of the paste and a different analysis too. The print is rich in $\mathrm{Ca}$ whereas the matrix has the characteristic analysis of a CSH gel type with higher Al proportion, as it is characteristic from these materials (7).

When the fibre is a polypropylene one, its surface is practically unaltered. This is in agreement with the results in the previous studies of the stabilisation of fibres and the better behaviour of the matrixes reinforced with these fibres than those reinforced with acrylic fibres. The impact strength of mortars

TABLA 6 (TABLE 6)

Ensayos de resistencia a impacto (Tests of impact strength)

\begin{tabular}{|c|c|c|c|c|c|c|}
\hline & \multicolumn{6}{|c|}{$\begin{array}{l}\text { NÚMERO DE IMPACTOS DE } 540 \mathrm{~kg} \text { DESDE } 100 \mathrm{~cm} \text { CAÍDA LIBRE } \\
\text { (NUMBER OF IMPACTS OF } 540 \mathrm{~kg} \text { FROM A FREE F.1LI. OF } 1(0) \mathrm{cm})\end{array}$} \\
\hline & \multicolumn{2}{|c|}{ MATRIZ A (MATRIX A) } & \multicolumn{2}{|c|}{ MATRIZ B (M1.ATRIX B) } & \multicolumn{2}{|c|}{ MATRIZ C (MATRIX C) } \\
\hline & $\begin{array}{l}\text { (' FISURA } \\
\left(I^{\prime \prime} \text { CRACK) }\right.\end{array}$ & $\begin{array}{c}\text { ROTURA } \\
\text { (FRACTURE) }\end{array}$ & $\begin{array}{l}\text { 1. FISURA } \\
\left(I^{\prime \prime} \text { CRACK) }\right.\end{array}$ & $\begin{array}{c}\text { ROTURA } \\
\text { (FRACTURE) }\end{array}$ & $\begin{array}{l}\text { I. FISURA } \\
\left(I^{\prime \prime}(C R A C K)\right.\end{array}$ & $\begin{array}{c}\text { ROTURA } \\
\text { (FRACTURE) }\end{array}$ \\
\hline $\begin{array}{c}\text { REFERENCIA } \\
\text { (STAND.1RD) } \\
\text { (sin fibra) Mithoul fibre) }\end{array}$ & 1 & 2 & 2 & 4 & 2 & 2 \\
\hline $\begin{array}{c}0.2 x \\
\text { ACRILICA } \\
\text { (ACRYLIC) }\end{array}$ & 3 & 8 & 2 & 4 & 2 & 3 \\
\hline $\begin{array}{c}1 \% \\
\text { ACRfl.ICA } \\
\text { (ACR R.IC) }\end{array}$ & 3 & 8 & 2 & 8 & 4 & 6 \\
\hline $\begin{array}{c}0,2 \% \\
\text { POI.IPROPILENO } \\
\text { (POL.YPROPY.ENE) }\end{array}$ & 1 & 9 & 2 & 6 & 3 & 4 \\
\hline $\begin{array}{c}1 \% \\
\text { POLIPROPILENO } \\
\text { (POLIPROPYENE) }\end{array}$ & 5 & 37 & 3 & 10 & 4 & 13 \\
\hline
\end{tabular}

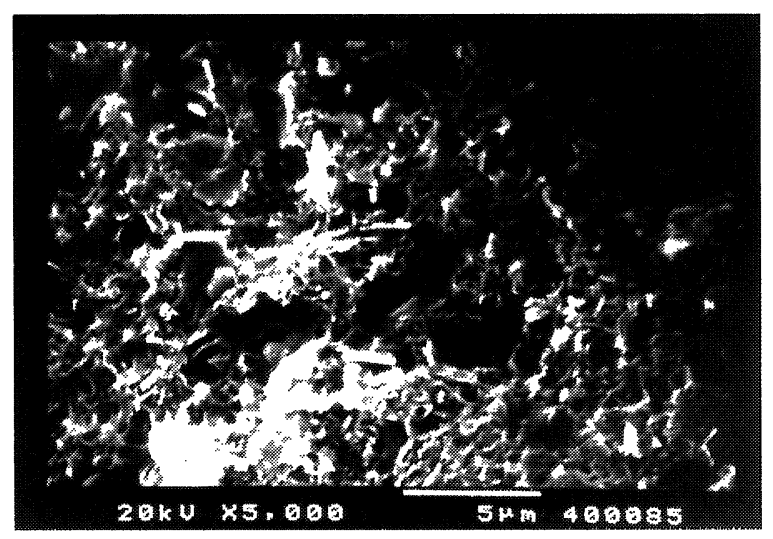

Figura 5.- Fibra acrílica en mortero de escoria activada. Presencia de depósitos y escamación.

Fïgure 5.- Acrylic fibre in activated slag mortar. Presence of deposits and flakes.

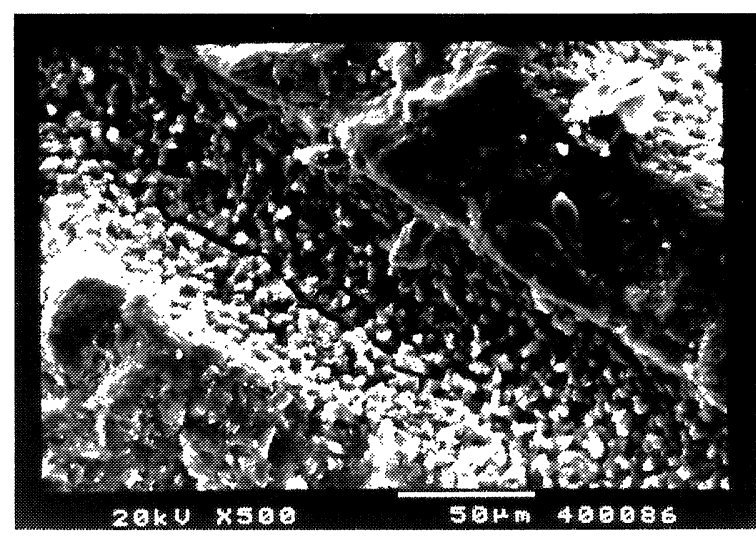

Figura 6.- Huella dejada por una fibra acrílica en un mortero de escoria activada.

Figure 6.- Printings left by an acrylic fibre in activated slag mortar 
de los morteros reforzados con fibras de polipropileno ( $1 \%$ ) es 4,6 veces mayor que en los morteros reforzados con fibras acrílicas.

\section{Matriz B (ceniza activada)}

Nuevamente las fibras acrílicas presentan en los morteros estudiados una alteración superficial importante. Se encuentran completamente recubiertas de depósitos, como pueden ser observadas en la Figura 7. Estos depósitos tienen diferente composición química, algunos son muy ricos en $\mathrm{Si} \mathrm{y} \mathrm{Ca}$, conteniendo también, en menor proporción, Al, Na y $\mathrm{Mg}$, y otros depósitos tienen contenidos altos en Si y $\mathrm{Al}$ y bajos en $\mathrm{Na}$ y $\mathrm{Ca}$. Estos últimos se asemejan a la composición de la matriz.

Las fibras de polipropileno tienen menos signos de alteración que las fibras acrílicas. En general estas fibras mantienen su morfología original y la cantidad de depósitos que contienen es muy inferior a la observada en las fibras acrílicas. Esto explica el mejor comportamiento de los morteros reforzados con las fibras de polipropileno, en su resistencia al impacto (son 2 veces más resistentes) que aquellos morteros de igual matriz, que contienen las fibras acrílicas.

Comparando estos resultados con los obtenidos con la matriz A, se evidencia que el papel de refuerzo de las fibras de polipropileno en esta última es mucho mayor que en los morteros de la matriz B. Ello puede ser atribuido a la diferente concentración de la disolución de $\mathrm{NaOH}$ (2M en la matriz A y $10 \mathrm{M}$ en la matriz B) y a la distinta temperatura de curado ( $\mathrm{T}^{\mathrm{a}}$ ambiente en la matriz A y $85^{\circ} \mathrm{C}$ durante las primeras 24 horas en la matriz B). El efecto del incremento de la temperatura sobre la estabilidad de la fibra de polipropileno en disoluciones fuertemente alcalinas se había comprobado que era negativo.

\section{Matriz C (ceniza/escoria activada)}

Las fibras acrílicas que refuerzan estos morteros tienen signos de alteración superficial pero son menos importantes que los observados en los morteros de la matriz B, siendo similares a los descritos en los morteros de la matriz A En la Figura 8 se puede apreciar el aspecto de estas fibras, con depósitos blancos cuyo análisis muestra que son ricos en $\mathrm{Na}$.

La textura superficial de las fibras de polipropileno en los morteros de esta matriz no se ve sustancialmente alterada. Sin embargo, es la probeta en la que se observan más huellas dejadas por las fibras. En la Figura 9 se puede observar una fibra y a su lado, a la derecha, la huella de otra. Los resultados obtenidos de reinforced with polypropylene fibres (1\%) is 4,6 times higher than that of the mortars reinforced with acrylic fibres.

\section{Matrix B (activated fly ash)}

Once again the acrylic fibres present an important alteration of the surface. They are completely covered by deposits as is observed in Figure 7. These deposits have different chemical composition, some of them are $\mathrm{Si}$ and $\mathrm{Ca}$ rich, containing minor proportions of $\mathrm{Al}, \mathrm{Na}$ and $\mathrm{Mg}$, and other deposits have high contents of Si and Al and low contents of $\mathrm{Na}$ and $\mathrm{Ca}$. The latter are similar to the matrix composition.

The polypropylene fibres have less alteration signs than the acrylic ones. In general, these fibres maintain their original morphology and the amount of deposits is very inferior to those observed in acrylic fibres. This explains the better behaviour of mortars reinforced with polypropylene fibres in their impact strength (2 times more resistant) than those mortars with the same matrix containing acrylic fibres.

Comparing these results to those obtained with matrix $A$, it is evident the higher reinforcement effect of the polypropylene fibres in this matrix than that obtained with matrix $B$. This can be attributed to the different concentration of $\mathrm{NaOH}$ solution (2M in matrix $A$ and $10 M$ in matrix $B$ ) and the different curing temperature (room temperature in matrix $A$ and $85^{\circ} \mathrm{C}$ in matrix $B$ during the first 24 hours). The effect of the temperature increase on the stability of the polypropylene fibres in strong alkaline media was verified to be negative.

\section{Matrix C (activated fly ash/slag)}

The acrylic fibres reinforcing these mortars have signs of surface alteration less important than those observed in matrix $B$, being similar to those described for the mortars with matrix A. In Figure 8, the aspect of these fibres can be observed, with white deposits whose analysis show them to be $\mathrm{Na}$ rich.

The surface texture of the polypropylene fibres in the mortars with this matrix shows no significant alteration. However, is the specimens that show more printings left by the fibres. In Figure 9, a fibre and a print at its right can be observed. The results 


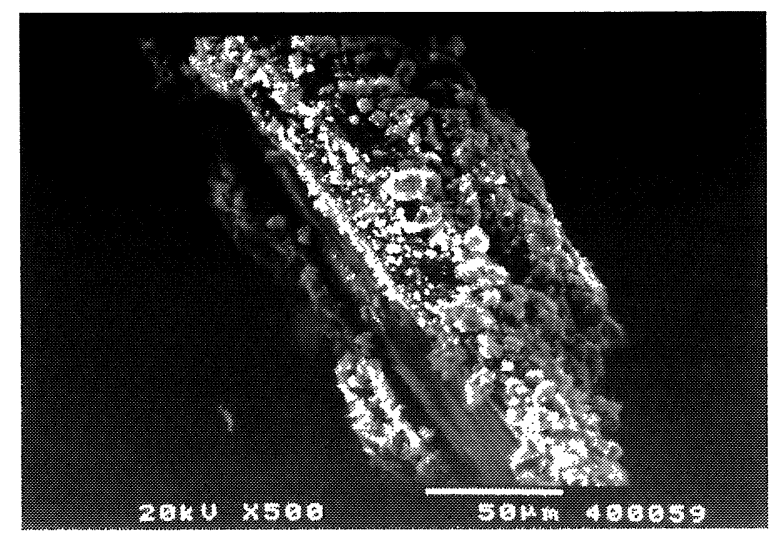

Figura 7.- Fibra acrílica. Mortero de ceniza activada. / (Acrylic fibre. Activated fly ash mortar).

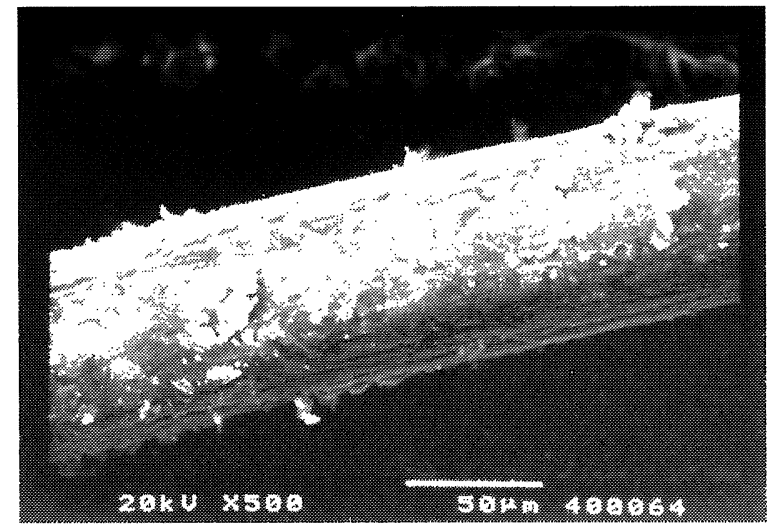

Figura 8.- Fibra acrilica. Mortero de ceniza/escoria activada.

Figure 8.- Acrylic fibre. Activated fly ash/slag mortar.

resistencia a rotura a impacto muestran que con la fibra de polipropileno, los valores obtenidos son inferiores a los obtenidos en los morteros de la matriz A y similares a los de la matriz B.

\subsection{Retracción al secado}

En la Figura 10 se presentan los resultados obtenidos de retracción al secado en función del tiempo para las tres matrices estudiadas. Las mayores retracciones se obtienen con la matriz A (escoria de horno alto activada) $(=1 \%)$ a los 21 días. Con las matrices $\mathrm{B}$ y C el porcentaje final de retracción al secado es del mismo orden, alcanzando valores máximos a los 21 días del 0,5-0,6\%. El papel jugado por las fibras en estos morteros es diferente dependiendo de la naturaleza de la matriz. Con la matriz $\mathrm{A}$, las fibras no reducen la retracción, incluso cuando la fibra de refuerzo es la acrílica se obtienen valores mayores de retracción que en el mortero sin fibra. Con la matriz $\mathrm{B}$ (ceniza activada), el resultado es opuesto. El mortero que contiene fibras acrílicas experimenta una retracción menor (alrededor de un 30\%) que el

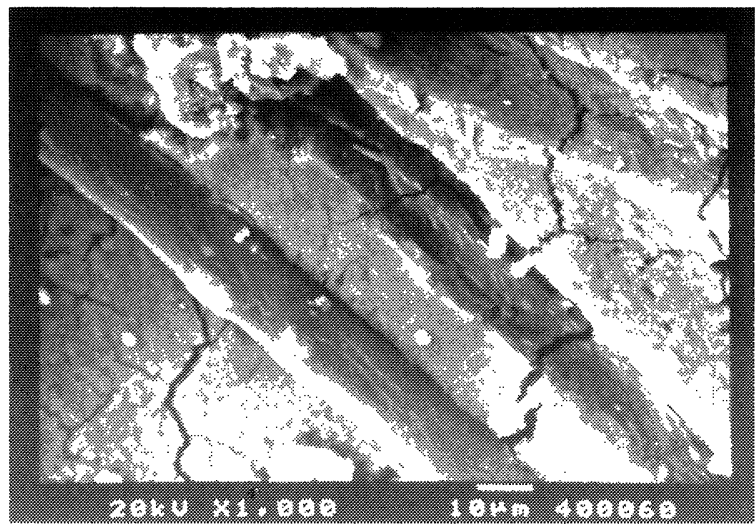

Figura 9.- Fibra de polipropileno. Mortero de ceniza/escoria activada

Figure 9.- Polypropylene fibre. Activated $f_{y}$ ash/slag mortar.

obtained at impact strength are lower than those obtained in mortars with matrix $A$ and similar to those of the matrix $B$.

\subsection{Drying shrinkage}

In Figure 10, the results obtained for drying shrinkage as a function of time for the three matrixes studied are shown. The higher shrinkage is obtained with matrix $A$ (activated blast furnace slag) (= 1\%) at 21 days. With matrixes $B$ and $C$, the final percentage of shrinkage is similar, reaching values at 21 days of 0,5-0,6\%. The role played by the fibres in these mortars is different depending on the nature of the matrix. With matrix A, fibres do not decrease shrinkage, even when the reinforcement fibre is acrylic, higher values of shrinkage than those of the mortar without fibre are obtained. With matrix $B$ (activated fly ash), the opposite result is obtained. The mortar containing acrylic fibres experiments lower shrinkage (about 30\%) than the mortar without fibres, however, the mortar reinforced with 

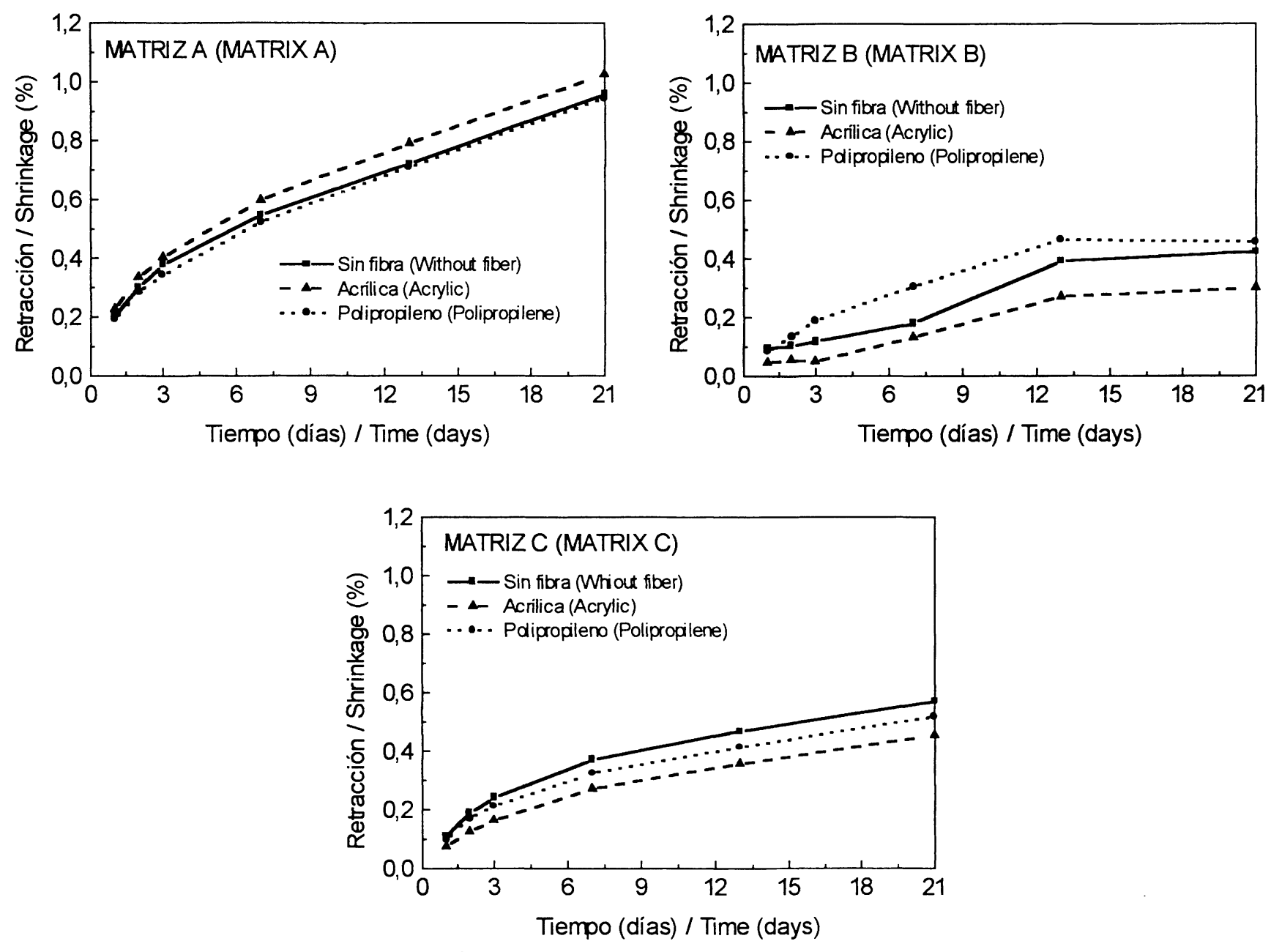

Figura 10.- Resultados de retracción al secado.

Figure 10.- Drying shrinkage results.

mortero sin fibras, sin embargo, el mortero reforzado con fibras de polipropileno la retracción final a los 21 días es ligeramente superior que en el mortero de referencia. Finalmente, con la matriz C (ceniza/escoria activada), los dos tipos de fibra reducen la retracción al secado (un $12 \%$ con la de polipropileno y un $20 \%$ con la acrílica).

Se deduce que, especialmente en el caso de la matriz A, el contenido de fibras utilizado ( $0,2 \%$ en volumen) es bajo, y sería recomendable valorar sobre la retracción al secado de estos morteros porcentajes mayores de fibra, especialmente de polipropileno.

\section{CONCLUSIONES}

Las principales conclusiones que se pueden extraer del presente trabajo son: polypropylene fibres has shrinkages at 21 days slightly superior than the reference mortar. Finally, with matrix $C$ (fly ash/slag), the two types of fibres decrease the drying shrinkage (12\% with polypropylene one and 20\% with acrylic one).

It is deduced that, especially in the case of matrix $A$, the fibre content $(0,2 \%$ in volume) is low, and it would be recommended to evaluate the drying shrinkage of these mortars higher fibre percentages, especially of polypropylene fibre.

\section{CONCLUSIONS}

The main conclusions extracted from the present work are: 
1) Las fibras acrílicas experimentan un proceso de hidrólisis/hidratación en medios fuertemente básicos, que se manifiesta con alteración de su textura superficial. Las fibras de polipropileno no sufren alteración en los medios alcalinos estudiados, aunque el incremento de la temperatura de curado produce modificaciones en la superficie de la misma.

2) Con bajos contenidos en fibra ( $0,2 \%$ en volumen), la tenacidad y el índice de tenacidad de estos morteros no se ve afectado. Con contenidos superiores (1\%) se produce un incremento en los correspondientes valores. Este incremento es mayor en los morteros de escoria activada alcalinamente.

3). Para las tres matrices estudiadas, las fibras de polipropileno incrementan la resistencia al impacto en mayor medida que las fibras acrílicas. El efecto de refuerzo es más significativo en la matriz $\mathrm{A}$ y cuando el contenido de fibra es del $1 \%$ en volumen. El estudio microestructural realizado sobre estos morteros ha demostrado que las fibras acrílicas presentan signos de alteración y gran cantidad de depósitos en su superficie, mientras que las de polipropileno se encuentran en mejor estado.

4) La retracción al secado de estos morteros se modifica dependiendo del tipo de matriz y fibra. En los morteros de escoria activada, las fibras no reducen la retracción. En los morteros de ceniza activada reforzados con las fibras acrílicas, la retracción es menor que cuando contienen fibras de polipropileno o carecen de ellas. Finalmente, en los morteros de ceniza/escoria activada, las dos fibras reducen la retracción al secado.

\section{AGRADECIMIENTOS}

Los autores quieren agradecer a la CICYT la subvención del proyecto de investigación MAT980792, sin cuyos fondos no hubiera sido posible realizar el presente trabajo. Los autores también quieren agradecer a J.L. García, A. Gil y S. Alonso por la preparación y ensayos de las probetas de mortero y a J.M. Llueca por su colaboración en los estudios microestructurales.
1) The acrylic fibres undergo a hydrolysis/hydration process in strong alkaline media showed by an alteration of the surface texture. The polypropylene fibres do not undergo this alteration in alkaline media, although the temperature increase produces changes in their surface.

2) With low fibre contents $(0,2 \%$ in volume), tenacity and tenacity index of these mortars is not affected. With higher contents (1\%) these values are increased.

3)For the three matrixes studied, the polypropylene fibres increase the impact strength more than the acrylic fibres. The reinforcement effect is more significative in matrix $A$ and when the fibre content is $1 \%$ in volume. The microstructural study carried out on these mortars has demonstrated that acrylic fibres present alteration signs and high amount of deposits in their surface, whereas polypropylene fibres remain in better state.

4)The drying shrinkage of these mortars is modified depending on the matrix type and the fibre type. In mortars of activated slag, fibres do not decrease the shrinkage. In mortars of activated fly ash reinforced with acrylic fibres, shrinkage is lower than that of mortars containing polypropylene fibres or not containing. Finally, in mortars of activated fly ash/ slag, the two fibres decrease the drying shrinkage.

\section{ACKNOWLEDGEMENTS}

The authors wish to thank to CICYT for funding this research trough MAT98-0792 project. The authors also wish to thank to J.L. Garcia, A. Gil and S. Alonso for the elaboration of specimens and the tests of the mortars and to J.M. Llueca for his collaboration in microstructural studies.

\section{BIBLIOGRAFÍA}

(1) S.D. Wang, X.C. Pu, K.L. Scrivener, P.L. Pratt. Alkali-activated cement and concrete. A review of properties and problems. Adv. Cem. Res. 7, 27 (1995) pp. 93-102

(2) V. Glukhovskij, Y. Zaitsev, V. Pakhomow. Slag-alkaline cements and concretes-structures, properties, technological and economical aspects of the use. Silicates Industriels, 10 (1983), pp. 197-200

(3) B. Talling, J. Brandstetr. Present state and future of alkali-activated slag concretes. Fly ash, Silica fumc, Slag and Natural Po\%zolans in Concrete. Procee. 3rd Intern. Conf. Trondheim, Norway (1989) SP114-74 (1989), pp. 1.519-1.545 
(4) F. Puertas. Cementos de escorias activadas. Situación actual y perspectivas de futuro. Materiales de Construcción, 239, 45 (1995), pp. 53-64

(5) C. Shi, R.L. Day. A calorimetry study of early hydration of alkali-slag cements. Cem. Concr. Res. Vol 25 (1995), pp. 1.333-1.346

(6) A. Fernández-Jiménez, J.G. Palomo, F. Puertas Alkali-activated slag mortars. Mechanical strength behaviour. Cem. Concr. Res. Vol.29(1999)pp. 1.313-1.321

(7) A. Fernández-Jiménez Cementos de escorias activadas alcalinamente: Influencia de las variables y modelización del proceso. Tesis Doctoral.Universidad Autónoma de Madrid (2000)

(8) A. Palomo, M.W. Grutzeck, M.T. Blanco Alkali-activated fly ashes: A cement for the future. Cem. Concr. Res. Vol. 29 (1999), pp. $1.323-1.329$

(9) A. Palomo, S. Alonso Recycling fly ashes for making precast components. $2^{\text {nd }}$ Intern. Symp on Prefabrication, Helsinki (2000)

(10) J.G.S. Van Jaarsveld, J.S.J. Van Deventer Effect of alkali metal activator on the properties of fly ash based geopolymers Ind. Eng. Chem. Res., Vol. 38 (1999), pp. 3.932-3.941

(11) F. Puertas, S. Martínez-Ramírez, S. Alonso, T. Vázquez Alkali-activated fly ash/slag cements. Strength behaviour and hydration products. Cem. Concr. Res., ((2000)

(12) T. Amat Hormigones reforzados con fibras acrilicas. Materiales de Construcción, Vol. 47, nº 247-248 (1997), pp. 43-56

(13) F. Acción, J. Gobantes, M.T. Blanco-Varela Cements reinforced by acrylic fibers. Infrared studies. I. Hydration and hydrolisis processes in the fibers". Cem. Concr. Res. Vol. 20 (1990), pp. 702-710

\section{Publicaciones del Instituto Eduardo Torroja - CSIC}

\section{Número monográfico de MATERIALES DE CONSTRUCCIÓN}

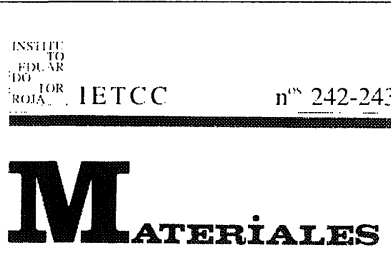

VIDRIO EN LA CONSTRUCCIÓN

$\mathbf{D E}$

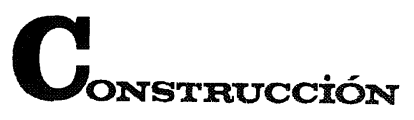

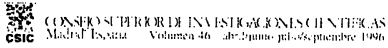

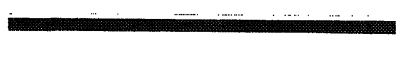

\section{EL VIDRIO EN LA} CONSTRUCCIÓN

$\left(n^{\circ} 242-243\right)$
- Procesos de alteración de las vidrieras medievales. Estudio y tratamientos de protección. (Alteration processes of medieval stained glass windows. Study and protection treatments). J. Ma Fernández Navarro.

- El efecto de la corrosión en vidrieras coloreadas.

(The effect of corrosion of stained glass windows).

J. Leissner.

- Formulación de vidrios absorbentes del calor. (Formulation of heat absorbing glasses).

P. Alvarez-Casariego y P. Mazón.

- Dimensionamiento de placas de acristalamiento para edificios mediante un modelo probabilístico de rotura. (A probabilistic model for failure design of glass plates in building).

A. Femández Canteli, I. Viña y A. Bernardo Sánchez.

- Caracterización de fibras en forma de lana de roca para aislamiento obtenidas a partir de basaltos canarios

(Characterization of fibers as rockwool for insulation obtained from canary islands basalts).

J. M. Cáceres, J. E. García Hernández y J. Mª Rincón.

- El GRC: Material compuesto de matriz inorgánica reforzado con fibras de vidrio AR.

(GRC: Composite material from an inorganic matrix reinforced with ar glass fibres).

P. I. Comino.

- Los materiales vitrocerámicos en la construcción.

(Glass-ceramic as building materials).

J. Ma Rincón y M. Romero.

- Gres porcelánico: Aplicaciones arquitectónicas, procesado y propiedades físico-mecánicas.

(Porcelainized stoneware: Architectural, processing and physico-mechanical properties).

T. Manfredini, M. Romagnoli y J. Mªncón.

Venta de ejemplares: distribución de Publicaciones

Instituto de Ciencias de la Construcción Eduardo Torroja

c/Serrano Galvache, s/n - 28033 Madrid

Tfino..(91)302.04.40-Fax:(91) 302.07 .00 